\title{
The Occurrence of Anagyrine in a Collection of Western American Lupines
}

\author{
A.M. DAVIS
}

\section{Abstract}

The alkaloid anagyrine found in some Lupinus species has been shown to cause the teratogenic condition known as "crooked calf disease." A collection of western American lupines held by the Western Regional Plant Introduction Station was grown at Pullman, Washington, to determine the extent and levels of anagyrine in these accessions. The plants were field grown on Tucannon soil, a fine-silty, mixed, mesic pachic Haploxerolls. Anagyrine determinations were made by gas/liquid chromatography. Accessions that were positive for anagyrine in June 1977 were resampled and verified in 1978. Anagyrine and total alkaloids were higher in April and markedly diminished by July. Seeds were higher in total alkaloids and anagyrine, when present, than was mature vegetation.

Lupines (Lupinus $\mathrm{sp}$.) frequently dominate the western range landscape in mid summer with their tall spikes of blue, purple, yellow, or white flowers. Speciation and species distribution are extensive in the western United States. Rydberg (1922) listed 80 species in the Rocky Mountains and adjacent plains. Tidestrom (1925), Dayton et al. (1937), Peck (1941), Davis (1952), Hermann (1966), and Hitchcock and Cronquist (1976) have also contributed to the knowledge of speciation and distribution of lupines in western range states.

Stockmen have long recognized the toxicity of lupines in the fall when the pods and seeds are ripe, but the vegetation was thought to be of lower toxicity during the growing season. Sampson (1952) and Stoddart and Smith (1955) indicated that most lupine poisoning occurs in sheep, but it may occur in other classes of livestock. The Agricultural Research Service (Anonymous 1968) noted that "crooked legs and other congenital deformities occur in newborn calves if cows graze toxic lupines between the 40th and the 70th days after breeding." Shupe (1970) distinguished between lupineinduced crooked calf disease and a similar genetically induced disease.

Keeler (1973a) determined that there were four major alkaloid peaks commonly associated with extracts from teratogenic lupines and established that the fourth sequential major peak contained the teratogenic agent. The toxicity of this peak was not appreciably influenced by the total alkaloid level in the plant tissues. Through the use of gas-chromatography/mass-spectroscopy, Keeler (1973b) established that peak 4 was sometimes made up of two compounds, anagyrine and $\beta$-isolupanine, with the latter, when present, making up less than $1 / 8$ of the material in the peak. Oral administration of the lupine extracts, with and without the peak 4 compounds, to cows in the sensitive period of pregnancy (40-70 days) produced classic lupine toxicity symptoms, but only cows given extracts containing peak 4 alkaloids produced crooked calves. The compound $\alpha$-isolupanine was not present in all teratogenic examples (Keeler 1973b).

\footnotetext{
Author is research agronomist, Western Regional Plant Introduction Station, U.S Dep. Agr. Agr. Res. Serv., Pullman, Washington 99164.

This report is a contribution of the Western Regional Plant Introduction Station, U.S. Dep. Agr., in cooperation with the College of Agriculture Research Center, Washington State University, Pullman 99164 . Scientific Paper No. 5375 of the latter. Manuscript received April 25, 1980.
}

Keeler (1976) and Keeler et al. (1977) found that anagyrine had broad occurrence in Lupinus caudatus (tailcup lupine) and $L$. sericeus (silky lupine). Keeler (1973a) reported that a large proportion of his sample from central Idaho contained anagyrine (peak 4) at levels of $1.44 \mathrm{~g} / \mathrm{kg}$ or higher. He also showed that lupines collected where crooked calf disease is unknown produced no anagyrine peaks or the quantities were less than $1.44 \mathrm{~g} / \mathrm{kg}$. The only exception was one location where the anagyrine levels were high enough to have produced crooked calves, but the area was only grazed with dry stock.

Anagyrine levels in vegetation were higher when the plants were small and growing vigorously. As flowering advanced and maturity approached, the alkaloid levels in leaves and stems diminished. The seed and seed pod levels were higher than any of the mature vegetative parts (Keeler et al. 1976). This would make late-breeding cows vlunerable, while mature seeds were still in the pods, during July, August, or September.

This paper reports the occurrence of anagyrine in 65 accessions from 19 perennial species of native, western American lupines.

\section{Materials and Methods}

The collection of lupines reported herein originated in the western U.S. from $460 \mathrm{~m}$ elevation for $L$. luteolus (bushy yellow lupine) and $L$. andersonii (Anderson's lupine) to $2300 \mathrm{~m}$ for $L$. alpestris (mountain silvery lupine); from dry sagebrush-dominated desert for tailcup lupine, $L$. erectus (tall silvery lupine), and silky lupine to wet meadows and streambanks for $L$. polyphyllus (Washington lupine) and $L$. burkei (Burk's lupine).

The PI 344000-numbered series was collected in 1968 from the state of Idaho and the immediate surroundings in Oregon, Montana, and Washington.

The collection was grown in 1976-1977-1978 at the SCS Plant Materials Center, Pullman, Washington. The soil was Tucannon, a fine-silty, mixed, mesic pachic haploxerolls with a gentle southward slope. Plants were established by seeding in greenhouse flats the first week in February 1976 and transplanted to the field in April. Spacing was $150 \mathrm{~cm}$ between rows, $45 \mathrm{~cm}$ between plants in the row, and $90 \mathrm{~cm}$ between accessions within the rows. Only natural precipitation was available after transplanting. Vegetation samples were collected in June 1977 by randomly picking representative stems, including leaves, flowers, and buds, if present. Stems from 10 plants of each accession were combined into a single sample. Samples were dried 24 hours in a thermal draft oven at $90^{\circ}$ $\mathrm{C}$ and ground in a to 20-mesh fineness.

The composite sample was thoroughly mixed and 2 subsamples of $0.5 \mathrm{~g}$ each were placed in a $200-\mathrm{ml}$ Ehrlenmeyer flask with $30 \mathrm{ml}$ of $5 \%$ acetic acid. The sample was shaken for 1 hour and filtered through a sintered glass funnel, under vacuum when necessary. The sample was washed twice with $15 \mathrm{ml}$ of the $5 \%$ acetic acid solution and all washings were combined. The filtrate was caught in $30 \mathrm{ml}$ of chloroform to which ammonium hydroxide had been added to bring the resultant solution to $\mathrm{pH}$ 9.5. The sample was partitioned into $30 \mathrm{ml}$ of chloroform three times and the chlorform 
Table 1. Distribution of anagyrine in a collection of Lupines from the western U.S.

\begin{tabular}{|c|c|c|c|}
\hline Species & $\begin{array}{c}\text { Number } \\
\text { tested }\end{array}$ & $\begin{array}{c}\text { Number } \\
\text { exceeding } \\
1.44 \mathrm{~g} / \mathrm{kg}\end{array}$ & $\begin{array}{l}\text { PI } \\
\text { Number }\end{array}$ \\
\hline $\begin{array}{l}\text { adsurgens Drew. } \\
\text { (Drew lupine) }\end{array}$ & 1 & $\mathbf{0}$ & \\
\hline $\begin{array}{l}\text { alpestris A. Nels. } \\
\text { (mountain silvery } \\
\text { lupine) }\end{array}$ & 2 & 1 & 344668 \\
\hline $\begin{array}{l}\text { andersonii S. Wats. } \\
\text { (Anderson's lupine) }\end{array}$ & 1 & 0 & \\
\hline $\begin{array}{l}\text { argenteus Pursh } \\
\text { (silvery lupine) }\end{array}$ & 5 & 4 & $\begin{array}{l}232571,344657 \\
344659,344662\end{array}$ \\
\hline $\begin{array}{l}\text { aridus Doug. } \\
\text { (dry ground lupine) }\end{array}$ & 1 & 0 & \\
\hline $\begin{array}{l}\text { burkei S. Wats. } \\
\text { (Burk's lupine) }\end{array}$ & 4 & 3 & $344664,344670,344675$ \\
\hline $\begin{array}{l}\text { caudatus Kell. } \\
\text { (tailcup lupine) }\end{array}$ & 6 & 4 & $\begin{array}{l}284724,344682,344716, \\
344724\end{array}$ \\
\hline $\begin{array}{l}\text { erectus Hend. } \\
\text { (tall silvery lupine) }\end{array}$ & 3 & 3 & $344678,344679,344681$ \\
\hline $\begin{array}{l}\text { evermannii Rydb. } \\
\text { (Everman lupine) }\end{array}$ & 1 & 1 & 344721 \\
\hline garfieldensis & 2 & 0 & \\
\hline $\begin{array}{l}\text { C.P. Smith } \\
\text { (Garfield lupine) }\end{array}$ & & & \\
\hline $\begin{array}{l}\text { humidicola A. Nel. } \\
\text { (lowland lupine) }\end{array}$ & 1 & 0 & \\
\hline $\begin{array}{l}\text { latifolius Lindl. } \\
\text { (broadleafed lupine) }\end{array}$ & 1 & 0 & \\
\hline $\begin{array}{l}\text { leucophyllus Doug. } \\
\text { (velvet lupine) }\end{array}$ & 9 & 6 & $\begin{array}{l}344658,344663,344666 \\
344674,344697,344707\end{array}$ \\
\hline $\begin{array}{l}\text { luteolus Kell. } \\
\text { (bushy yellow lupine) }\end{array}$ & 1 & $\mathbf{0}$ & \\
\hline $\begin{array}{l}\text { nevadensis Hell. } \\
\text { (Nevada lupine) }\end{array}$ & 1 & 0 & \\
\hline $\begin{array}{l}\text { oreganus Hell. } \\
\text { (Oregon lupine) }\end{array}$ & 1 & 0 & \\
\hline $\begin{array}{l}\text { polyphyllus Lindl. } \\
\text { (Washington lupine) }\end{array}$ & 1 & 1 & 232580 \\
\hline sericeus Pursh & 22 & 7 & $\begin{array}{l}344654,344671,344683 \\
344695,344702,344725 \\
356830\end{array}$ \\
\hline species & 2 & II & 344696 \\
\hline
\end{tabular}

'Commercial cultivar (R ussell Hybrid)

was evaporated at $40^{\circ} \mathrm{C}$ and $-1 / 2$ atmosphere vacuum on a rotary evaporator. Analysis of seed was complicated by the formation of a gel when the chloroform and acetic acid were mixed. This was overcome by centrifuging the mixture and drawing the chloroform and alkaloid from below the gel. The dry residue was taken up in $2.5 \mathrm{ml}$ of absolute Ethanol containing $1 \mathrm{~g} \mathrm{4-aminoantipyrene} \mathrm{per}$ $500 \mathrm{ml}$ of ethanol as an internal standard for gas chromatography. The alkaloids were separated and quantified using a gas chromatograph equipped with flame ionization detector, a glass column 0.63 $\mathrm{cm}$ in diameter and $183 \mathrm{~cm}$ long, packed with Anakrom ABS2 90-100 mesh and 3\% OV-17 liquid phase. Separation was isother$\mathrm{mal}$ at $240^{\circ} \mathrm{C}$. The carrier gas was nitrogen at $40 \mathrm{cc} / \mathrm{min}$ at 2.8 $\mathrm{kg} / \mathrm{cm}^{2}$.

Reference samples were furnished by Dr. Richard Keller, U.S. Dep. Agr. Poisonous Plants Research Laboratory, Logan, Utah 84321. Identification and quantification of anagyrine were based on those samples.

\section{Results and Discussion}

The lupine species tested for anagyrine in June 1977 and presented in Table 1. The number of accessions in each species tested and the number of accessions that contained anagyrine in excess of

Mention of a trademark or proprietary product does not constitute a guarantee or warranty of the product by the USDA and does not imply its approval to the exclusion of other products that may also be suitable. the critical level of $1.44 \mathrm{~g} / \mathrm{kg}$ reported by Keller (1973a) are also given. Accessions from nine species did not show any anagyrine, whereas accessions from 10 species and a commercial ornamental cultivar had anagyrine in sufficient quantities to cause crooked calves. Lupinus lepidus Dougl. ex. Lindl. (prairie lupine) is a well known poisonous lupine. Its teratogenicity was not studied because it was not identified in the collection.

Tailcup lupine and silky lupine are the two species previously reported as causing crooked calves. From the data presented, some collections of these species had low levels of anagyrine and would present no hazard during the sensitive period of pregnancy. Indicting or exonerating a whole species on the basis of only one or two samples is hazardous. The possibility of making an incorrect decision about a species is exemplified by only three of the five accessions of tailcup lupine and seven of the 22 accessions of silky lupine having toxic levels of anagyrine. Even though there were eight species without anagyrine, the limited sampling of these species cannot be construed to mean that all collections of these species will also be free of the teratogen.

Levels of anagyrine and total alkaloids found in the initial screening of tailcup lupine and silky lupine are presented in Table 2. Anagyrine does not make up a major portion of the total alkaloid spectrum in tailcup lupine but when present in silky lupine, anagyrine is frequently the predominant alkaloid. An exception was silky lupine, PI 344671 , with $11.58 \mathrm{~g} / \mathrm{kg}$ total alkaloid and only $1.18 \mathrm{~g} / \mathrm{kg}$ of anagyrine. Accessions with over 9.00

Table 2. The distribution of anagyrine and total alkaloids in tailcup lupine and silky lupine. 1

\begin{tabular}{|c|c|c|c|c|}
\hline & \multicolumn{2}{|c|}{ Anagyrine $(\mathrm{g} / \mathrm{kg})$} & \multicolumn{2}{|c|}{ Total alkaloids ( $\mathbf{g} / \mathbf{k g})$} \\
\hline & Vegetation & Seeds & Vegetation & Seeds \\
\hline \multicolumn{5}{|c|}{ Tailcup lupine } \\
\hline 284724 & 6.44 & 4.70 & 23.75 & 12.26 \\
\hline 344682 & 4.27 & 5.00 & 17.19 & 19.10 \\
\hline 344716 & 1.27 & 12.67 & 8.96 & 27.00 \\
\hline 344718 & -2 & - & 7.95 & 19.48 \\
\hline 344722 & 2.47 & 6.58 & 16.06 & 28.80 \\
\hline 344724 & 2 & 2.88 & 18.18 & 21.66 \\
\hline \multicolumn{5}{|c|}{ Silky lupine } \\
\hline 232581 & - & - & 7.99 & 11.98 \\
\hline 344649 & - & - & 8.92 & 10.22 \\
\hline 344652 & - & - & 9.14 & 21.32 \\
\hline 344654 & - & - & 5.63 & 14.90 \\
\hline 344671 & 1.18 & 4.47 & 11.58 & 10.65 \\
\hline 344676 & 1.08 & 3.83 & 3.82 & 16.16 \\
\hline 344680 & ) & - & 4.29 & 11.86 \\
\hline 344685 & - & - & 4.13 & 14.04 \\
\hline 344683 & 3 & 4.88 & 2.63 & 7.79 \\
\hline 344686 & ) & - & 5.48 & 11.51 \\
\hline 344687 & - & - & 3.08 & 11.07 \\
\hline 344689 & - & 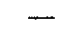 & 7.89 & 14.83 \\
\hline 344694 & - & - & 5.90 & 25.47 \\
\hline 344695 & 2.16 & 5.70 & 2.93 & 12.18 \\
\hline 344698 & - & - & 9.40 & 15.47 \\
\hline 344702 & 2.51 & 5.70 & 5.70 & 15.17 \\
\hline 344717 & 3.04 & 8.93 & 5.63 & 16.84 \\
\hline 344719 & - & - & 6.78 & 19.48 \\
\hline 344720 & - & - & 9.45 & 24.10 \\
\hline 344725 & - & - & 7.31 & 19.21 \\
\hline 356829 & - & - & 6.40 & 25.78 \\
\hline 356830 & 3 & 2.15 & 1.47 & 21.20 \\
\hline
\end{tabular}

June 1977 harvest

${ }^{2}$ No anagyrine detected.

${ }^{3}$ Less than $1 \mathrm{~g} / \mathbf{k g}$.

$\mathrm{g} / \mathrm{kg}$ total alkaloids but no anagyrine were PI 344652, 344598 and 344720 .

Tailcup lupine was generally higher in total alkaloids and anagyrine than silky lupine. Total alkaloids and anagyrine content va ried independently in both species. The highest total alkaloid level in 


\begin{tabular}{|c|c|c|c|c|c|c|c|c|c|}
\hline \multirow[b]{4}{*}{ PI No. } & \multirow[b]{4}{*}{ Species } & \multicolumn{5}{|c|}{ Anagyrine $(\mathrm{g} / \mathrm{kg})$} & \multicolumn{3}{|c|}{ Total alkaloids $(\mathrm{g} / \mathrm{kg})$} \\
\hline & & \multicolumn{5}{|c|}{ Harvest Date } & \multicolumn{3}{|c|}{ Harvest Date } \\
\hline & & \multicolumn{4}{|c|}{ (Vegetation) } & \multirow[t]{2}{*}{ Seed } & \multicolumn{2}{|c|}{ (Vegetation) } & \multirow[t]{2}{*}{ Seed } \\
\hline & & $4 / 19$ & $5 / 10$ & $6 / 6$ & $7 / 5$ & & $6 / 6$ & $7 / 5$ & \\
\hline 344668 & mountain silvery lupine & 8.77 & 5.95 & 3.22 & 3.21 & 4.83 & 14.85 & 12.86 & 36.67 \\
\hline 344657 & silvery lupine & 12.15 & 9.58 & 2.35 & 2.62 & 4.63 & 12.98 & 11.88 & 14.58 \\
\hline 344659 & silvery lupine & 5.82 & 6.50 & 1.52 & 1.54 & 2.49 & 15.23 & 5.66 & 14.91 \\
\hline 344662 & silvery lupine & 4.47 & 4.52 & 1.49 & 1.38 & 4.83 & 21.81 & 12.49 & 27.89 \\
\hline 284724 & tailcup lupine & 15.37 & 9.83 & 6.44 & 6.32 & 4.70 & 23.75 & 7.75 & 12.26 \\
\hline 344682 & tailcup lupine & 12.36 & 5.33 & 4.27 & 4.67 & 5.00 & 17.19 & 5.00 & 19.10 \\
\hline 344722 & tailcup lupine & 11.84 & 5.11 & 2.47 & 3.17 & 6.58 & 16.08 & 7.58 & 28.80 \\
\hline 344724 & tailcup lupine & 4.24 & 1.35 & 2 & 2 & 2.88 & 18.18 & 6.58 & 21.66 \\
\hline 344721 & Everman lupine & 16.93 & 8.16 & 4.71 & 2.77 & 5.83 & 15.07 & 6.82 & 25.27 \\
\hline 344678 & tall silvery lupine & 9.48 & 2.37 & 1.45 & 1.66 & 6.72 & 13.38 & 6.72 & 17.20 \\
\hline 344679 & tall silvery lupine & 4.96 & 2.84 & 1.50 & 1.52 & 7.15 & 12.69 & 7.15 & 13.27 \\
\hline 344658 & velvet lupine & 6.09 & 1.12 & 2 & 2 & 5.17 & 15.23 & 2.89 & 28.95 \\
\hline 232580 & Mt. Rose lupine & 14.57 & 12.20 & 6.03 & 6.23 & 6.29 & 14.51 & 8.09 & 15.23 \\
\hline 344671 & silky lupine & 9.54 & 5.76 & 1.18 & 1.06 & 4.47 & 11.58 & 3.63 & 10.65 \\
\hline 344676 & silky lupine & 4.30 & 3.54 & 1.08 & 2.01 & 3.82 & 6.21 & 3.82 & 16.62 \\
\hline 344702 & silky lupine & 12.16 & 5.22 & 2.51 & 1.57 & 5.70 & 12.48 & 5.48 & 15.17 \\
\hline 344696 & species & 6.45 & 4.12 & 4.22 & 3.02 & 2.41 & 13.94 & 12.90 & 8.75 \\
\hline
\end{tabular}

11978 harvest.

2Less than $1 \mathrm{~g} / \mathrm{kg}$ anagyrine.

tailcup lupine was found in PI 344724 at $18.18 \mathrm{~g} / \mathrm{kg}$, with an associated anagyrine level of less than $1 \mathrm{~g} / \mathrm{kg}$. PI $344682 \mathrm{had} 17.19$ $\mathrm{g} / \mathrm{kg}$ total alkaloids and $4.27 \mathrm{~g} / \mathrm{kg}$ anagyrine in June 1977 .

Young rapidly growing tissue was equal to or higher in anagyrine than seeds (Table 3). By the June sampling dates, the levels in vegetation had dropped and remained below those found in seeds from the same accessions. The highest total alkaloid level found in seeds of tailcup lupine was $28.80 \mathrm{~g} / \mathrm{kg}$ in PI 344722 , with $6.58 \mathrm{~g} / \mathrm{kg}$ anagyrine. Seeds of mountain silvery lupine, PI 344688, had the highest total alkaloid content of this species at $36.67 \mathrm{~g} / \mathrm{kg}$ and also contained $4.83 \mathrm{~g} / \mathrm{kg}$ anagyrine.

Total alkaloids cannot be ignored. Lupine toxicity must be considered in addition to crooked disea se if strains of lupines a re to be used in revegetating ranges. Data presented in Tables 2 and 3 indicate that considerable variation exists in total alkaloids. Vegetation of silky lupine, PI 344683, had the lowest total alkaloids of any accession tested in June $1977,2.63 \mathrm{~g} / \mathrm{kg}$. Seed of this accession contained only $7.79 \mathrm{~g} / \mathrm{kg}$ total alkaloids. Anagyrine was not detected in either forage or seed of this accession.

The results of resampling the accessions that were anagyrine positive in 1977 are presented in Table 3. Those accessions that failed to show anagyrine throughout the sampling period wert excluded, even though there was anagyrine present in the young rapidly growing plants (see Table 1). The data agree with the conclusion of Keller et al. (1976) that anagyrine and total alkaloids are high in the spring and reduced as plants mature throughout bloom and seed set.

Lupine seeds have been considered a primary source of poisoning. The accessions listed in Table 3 varied from $2.41 \mathrm{~g} / \mathrm{kg}$ anagyrine the ornamental cultivar, PI 344696, to $7.15 \mathrm{~g} / \mathrm{kg}$ in tall silvery lupine, PI 344679 . The highest level of total alkaloids $(55.66 \mathrm{~g} / \mathrm{ka})$ was found in Nevada lupine, PI 356828, an accession that contained no anagyrine in the seeds. No accession produced anagyrine in the seeds when there was none in the vegetation.

Lupines native to the western U.S. exhibit varying amounts of anagyrine and total alkaloids. Variation within species and accessions is available for exploitation. The variation in anagyrine and total alkaloids within a species can be utilized to develop non-toxic varieties for range improvement. The following accessions were either free of anagyrine or had concentrations below the critical level of $1.44 \mathrm{~g} / \mathrm{kg}$ : Drew Lupine ( $L$ adsurgens). PI 284704; mountain silvery lupine, PI 356827; dry ground lupine ( $L$ aridus), PI 344693; silvery lupine, PI 232569, PI 232570; Burk's lupine, PI 344672; tailcup lupine, PI 344718, P1 344722; Garfield lupine (L. garfiedensis), PI 344648, PI 344684; lowland lupine (L. humidicola), PI 273275; broadleafed lupine ( $L$ latifolius), PI 284720; velvet lupine (L. leucophyllos), PI 344650, PI 344656, PI 344706; bushy yellow lupine, PI 284722; Nevada lupine, PI 356828; silky lupine, PI 232581, PI 344649, PI 344652, PI 344654, PI 344680, PI 344685, PI 344686, PI 344687, PI 344689, PI 344694, PI 344698, PI 344719, PI 344720 , PI 356829 and $L$. sp. 284727 . It should be possible to develop low total alkaloid and essentially anagyrine-free strains from the major species for reseeding, thus reducing the level of lupine toxicity and crooked calf disease now experienced by some ranchers in many sections of the western states. If these perennial, long-lived legumes are to be used for range reseeding, an intensive program of breeding is needed.

\section{Literature Cited}

Anonymous, 1968. 22 plants poisonous to livestock in the western states. U.S. Dep. Agr. Agr. Inform. Bull. No. 327.

Davis, R.J., 1952. Flora of Idaho, Wm. C. Brown Co. 828 p.

Dayton, W.A., T. Lommasson, B.C. Park, C.A. Kutzleb, O. Julander, ..R. Standing, S.S. Hutchings, L.W. Swift, E.P. Clif, D.W. Hayes, and M.L. Bomhard, 1937. Range Plant Handbook. U.S. Dep. Aer. Forest Serv. GPO.

Hermann, F.J., 1966. Notes on Western Range Forbs: Cruciferae through Compositae. U.S. Dep. Agr. Forest Serv. Agr. Handbook No. 293. 365 p.

Hitchcock, C.L., and A. Cronquist, 1976. Flora of the Pacific Northwest.p. 265-269. (Washington) Univ. Washington Press. $730 \mathrm{p}$

Keeler, R.F., 1973a. Lupine alkaloids from teratogenic and nonteratogenic lupines. I. Correlation of crooked calf disease incidence with alkaloid distribution determined by gas chromatography. Teratology 7:23-30.

Keeler, R.F., 1973b. Lupine alkaloids from teratogenic and nonteratogenic lupines. Il. Identification of the major alkaloids by tandem gas chromatography-mass spectrometry in plants producing crooked calf disease. Teratology 7:31-36.

Keeler, R.F., 1976. Lupine alkaloids from teratogenic and nonteratogenic lupines. III. Identification of Anagyrine as the probable teratogen by feeding trials. J. Toxicol. Environ. Health 1:882-898.

Keeler, R.F., E.H. Cronin, and J.L. Shupe, 1976. Lupine alkaloids from teratogenic and nonteratogenic lupines. IV. Concentration of total alkaloids. Individual major alkaloids and the teratogen Anagyrine as a function of plant part and the stage of growth and their relationship to crooked calf disease. J. Toxicol. Environ. Health 1:899-908.

Keeler, R.F., L.F. James, J.L. Shupe, and K.R. Van Kampen, 1977. Lupine induced crooked calf disease and a management method to reduce incidence, J. of Range Manage. 30:97-102. 
Peck, M.E., 1941. A manual of the higher plants of Oregon. Binfords \& Mart, Portland, Ore. $866 \mathrm{p}$.

Rydberg, P.A., 1922. Flora of the Rocky Mountains and adjacent plains. Hafner Publishing Co., New York. 1144 p.

Sampson, S.W., 1952. Range Management, Principles and Practices. John Wiley \& Sons, Inc. $570 \mathrm{p}$.

Shupe, J.L., 1970. Crooked Calf Syndrome, in Bovine Medicine and
Surgery and Herd Health Management, by G.W. Gibbons, E.J. Catcott and J.F. Smithcors. American Veterinarian Pub. 847 p.

Stoddart, L.A., and A.D. Smith, 1955. Range Management. McGraw-Hill Book Co. 433 p.

Tidestrom, I., 1925. Flora of Utah and Nevada. Contributions from the United States National Herbarium. Vol. 25. GPO. Washington D.C. 665 p. 